\title{
Enjoying the Quiet Life? Corporate Governance and Managerial Preferences
}

\section{Citation}

Bertrand, Marianne, and Sendhil Mullainathan. 2003. Enjoying the quiet life? Corporate governance and managerial preferences. Journal of Political Economy 111(5): 1043-1075.

\section{Published Version}

http://dx.doi.org/10.1086/376950

\section{Permanent link}

http://nrs.harvard.edu/urn-3:HUL.InstRepos:3429713

\section{Terms of Use}

This article was downloaded from Harvard University's DASH repository, and is made available under the terms and conditions applicable to Other Posted Material, as set forth at http:// nrs.harvard.edu/urn-3:HUL.InstRepos:dash.current.terms-of-use\#LAA

\section{Share Your Story}

The Harvard community has made this article openly available.

Please share how this access benefits you. Submit a story.

Accessibility 


\title{
Enjoying the Quiet Life? Corporate Governance and Managerial Preferences
}

\author{
Marianne Bertrand \\ University of Chicago, National Bureau of Economic Research, and Centre for Economic Policy \\ Research
}

\section{Sendhil Mullainathan}

Massachusetts Institute of Technology and National Bureau of Economic Research

\begin{abstract}
Much of our understanding of corporations builds on the idea that managers, when they are not closely monitored, will pursue goals that are not in shareholders' interests. But what goals would managers pursue? This paper uses variation in corporate governance generated by state adoption of antitakeover laws to empirically map out managerial preferences. We use plant-level data and exploit a unique feature of corporate law that allows us to deal with possible biases associated with the timing of the laws. We find that when managers are insulated from takeovers, worker wages (especially those of white-collar workers) rise. The destruction of old plants falls, but the creation of new plants also falls. Finally, overall productivity and profitability decline in response to these laws. Our results suggest that active empire building may not be the norm and that managers may instead prefer to enjoy the quiet life.
\end{abstract}

The research is this paper was conducted while we both were research associates at the Boston Research Data Center. Research results and conclusions expressed are those of the authors and do not necessarily indicate concurrence by the Bureau of the Census. This paper has been screened to ensure that no confidential data were revealed. We have benefited immensely from the detailed comments of the editor (John Cochrane), three anonymous referees, and many of our colleagues. We are also extremely grateful to seminar participants at numerous institutions for their helpful suggestions. Etienne Comon provided excellent research assistance. The American Compensation Association and Princeton Industrial Relations Section generously provided financial support.

[Journal of Political Economy, 2003, vol. 111, no. 5]

(C) 2003 by The University of Chicago. All rights reserved. 0022-3808/2003/11105-0001\$10.00 


\section{Introduction}

In the United States, managers own very little of the firms they manage. In a representative sample of large public firms, 90 percent of the chief executive officers (CEOs) owned less than 5 percent of their company (Ofek and Yermack 2000). This small ownership can create moral hazard because managers bear little financial costs if they pursue their own goals rather than maximize shareholder wealth. Corporate governance mechanisms - such as takeover threats, large shareholders, or effective boards-may reduce this moral hazard problem (see Shleifer and Vishny [1997] for a survey). For example, if managers fear a hostile takeover and the resulting job loss, they may more closely pursue shareholder interests. But the statement that corporate governance reduces moral hazard is not a very specific one. It is hard to translate into predictions about observable behavior. How would weakening corporate governance affect workers' wages, for example? What about employment, plant creation, or plant destruction? Without understanding what managerial preferences actually are, one cannot easily integrate governance into broader discussions about labor markets, investment, or the macroeconomy. In this paper we examine how corporate governance affects firm behavior on a variety of dimensions and in the process hope to gain some insights about managerial preferences.

Two obstacles hinder any empirical attempt to study managerial preferences. First, data limitations constrain the specific outcomes that can be studied. Standard corporate data sources usually report only balance sheet and stock market information. Typical outcome measures in these data, such as accounting profits, book value of assets, or stock market returns, are very aggregate; more detailed outcomes such as wages, employment, or precise investment activity are difficult or even impossible to measure. We deal with this data problem by using a unique match between the Longitudinal Research Database (LRD) and Compustat. The LRD provides plant-level data for the U.S. manufacturing sector. This data set allows us to track wages, employment, plant creation, plant destruction, and productivity (among other variables) by individual plants over time. The match to Compustat allows us to link these detailed variables to balance sheet and stock market information.

A second and even more serious obstacle is the endogeneity of corporate governance. Firms with better and worse governance probably also differ on other, unobservable, dimensions. So comparing managerial behavior between firms with good and bad governance may capture the effect of these unobservable differences rather than the effect of governance. Similarly, changes in governance within a firm may be accompanied by other unobservable changes. For example, many studies find improvements in firm performance following ownership 
changes (such as Brown and Medoff [1988], Kaplan [1989], Lichtenberg and Siegel [1990], and Lichtenberg [1992]). While extremely informative about the covariates of ownership changes, these studies are less informative about the effects of governance since other factors, such as the management team, may also be changing with the new ownership. Moreover, actual takeovers or leveraged buyouts (LBOs) may selectively target firms with better future prospects. As Grinblatt and Titman (1998, pp. 686-87) put it, "Sponsors [of an LBO] are unlikely to consider an LBO of a firm for which business prospects are forecasted to be unfavorable .... Firms that undergo LBOs are likely to experience subsequent increases in their cash flows even without productivity improvements." Similar concerns exist for other sources of between- or within-firm variation in governance. ${ }^{2}$

We attempt to deal with this endogeneity problem by using the passage of antitakeover laws to measure changes in corporate governance. These laws, passed by many states at different points in time, restricted hostile takeovers of firms incorporated in the legislating states. The reduced fear of hostile takeover means that an important disciplining device has become less effective and that corporate governance overall was reduced. ${ }^{3}$ These laws avoid the endogeneity problem to the extent that they are passed by states and are not endogenously driven by firmspecific conditions. Unlike firm-specific takeover defenses, laws are not passed on a firm-by-firm basis. Of course, one might still worry about the political economy of the laws, that is, that they may have been passed because of changing economic climates in a state. We return to this issue below.

Our analysis of the laws focuses on two types of outcomes: firm-level and plant-level. To infer the laws' effect for firm-level outcomes, we simply compare changes in outcomes around the time of a law for firms affected by the law to changes for firms unaffected by the law. The bulk of our analysis, however, focuses on plant-level outcomes. In that part of the paper, we exploit a unique feature of corporate law to better control for changing economic conditions specific to passing states. When a state passes an antitakeover law, all the firms incorporated in that state are affected, independently of their state of location. Since many

\footnotetext{
${ }^{1}$ Empirically, Bradley (1980), Dodd (1980), and Bradley, Desai, and Kim (1983) show that while target share prices decline, on average, following the failure of a takeover bid, they stay higher than the price that prevailed prior to the bid, suggesting that bidders may have private information about targets.

${ }^{2}$ For example, a management team that is so concerned about takeover to adopt a poison pill may be expecting very poor performance in the future (DeAngelo and Rice 1983; Jarrell and Poulsen 1987).

${ }^{3}$ These laws also reduce a firm's ability to be a raider. But since this reduced ability is common to all firms, independent of a raider's state of incorporation, our identification strategy will not pick up on this effect.
} 
of the corporations in our sample (roughly three-quarters) have plants located in different states, this feature means that we can completely control for shocks specific to a state of location and year. Because the state of incorporation is a legal concept, with little economic meaning, such controls account for most economic and political shocks coincident with the laws. ${ }^{4}$ For a simple illustration of our methodology, consider two plants located in New York, one of which belongs to a Delaware incorporated firm and the other to a California incorporated firm. When Delaware passes its law in 1988, we can compare the changes in outcomes in the Delaware incorporated plant with the changes in the California incorporated plant. Since both are located in New York, they will be affected by roughly similar economic and political shocks, but only the plant belonging to the Delaware firm will be affected by the change in corporate law. Hence, we can control for any political economy or business cycle factors that may have coincided with or led to the passage of the antitakeover law.

Following this methodology, we find that production workers' wages rise by about 1 percent in the protected plants and white-collar wages rise by about 4 percent. We also find large effects for plant creation and destruction. Not only does the rate of plant destruction fall, but the rate of plant creation also falls. When we examine the net effect on overall firm size, we find that the reductions in plant creation and destruction roughly offset each other, so there is no statistically significant change in firm size. Similarly, we find no effect on capital expenditures.

While the changes we document seem to suggest that the antitakeover laws also reduced efficiency, this need not be the case. Some models have suggested that reducing takeover threats may actually enhance productive efficiency (Shleifer and Summers 1988; Stein 1988; Blair 1995). We therefore directly investigate the impact of the antitakeover laws on plant-level measures of productivity and profitability. We find that total factor productivity declines following antitakeover legislation. Return on capital also falls by nearly 1 percent. These findings support the idea that better governance does in fact improve economic performance and does not involve only a transfer of rents to shareholders.

What do these results suggest about managerial preferences? First, managers appear to care more about workers, especially white-collar workers, than shareholders do. ${ }^{5}$ But, in contrast to stakeholder theories in which this increased attention to workers improves productive effi-

\footnotetext{
${ }^{4}$ In practice, antitakeover legislation is by far the most important development in corporate law over the time period we study.

${ }^{5}$ This care for workers may result from a desire to avoid conflict with unions, ease interactions with workers, or be surrounded by higher-quality employees. The important point is that workers will positively enter the utility function of the manager in a reducedform model.
} 
ciency, we actually find that productive efficiency falls. Second, we see that empire-building models of managerial preferences (Baumol 1959; Marris 1964; Williamson 1964) do not fit our data well. These models predict in reduced form that a weakening corporate governance would lead managers to increase firm size. In contrast, we find that while weakening the threat of takeover reduces plant destruction, it also reduces plant creation, without any net effect on firm size. Our results instead seem to fit better a different class of models, which we refer to as "quiet life" models. Very much as in Hicks's (1935) suggestion that the best of all monopoly profits is a quiet life, poorly governed managers may prefer to avoid the difficult decisions and costly efforts associated with shutting down old plants or starting new plants. The wage results may also fit well into this quiet life view if high wages are a way for managers to buy peace with their workers. ${ }^{6}$ This is quite interesting because existing models of capital structure and governance instead emphasize a managerial preference for empire building.

\section{State Takeover Laws}

We begin by describing takeover laws. A new era in the regulation of takeover activity in the United States began with the Williams Act, a federal statute passed in 1968. The Williams Act provided for detailed disclosure requirements, an antifraud system, and other measures to protect target shareholders during the tender offer process. Individual states greatly extended the Williams Act by passing their own statutes in the 1970s. These are known as the "first generation" of state antitakeover laws. The first-generation laws were deemed unconstitutional by the Supreme Court in 1982 (Edgar v. Mite Corp.) primarily because of their excessive jurisdictional reach, which applied far beyond corporations chartered in the state. In response to this decision, states hesitantly began a second wave of antitakeover statutes that dealt with some of the issues raised by the court. To the surprise of many, these statutes were declared constitutional by the Supreme Court in 1987 (CTS v. Dynamics Corp.). ${ }^{7}$ This decision triggered a third generation of even more stringent state laws regulating takeovers.

The most stringent of the second- and third-generation laws were known as business combination laws, which will be the focus of our study

\footnotetext{
${ }^{6}$ Note that other models may have some similar reduced-form implications. For example, some career concern models may lead managers to avoid undertaking projects that might signal their ability. The important point is that, in reduced form, managers do not appear to be interested in enlarging the firm.

${ }^{7}$ First-generation laws were declared unconstitutional because they violated the commerce clause and to a lesser extent the supremacy clause of the U.S. Constitution. The second-generation laws were deemed constitutional primarily because they restricted the jurisdiction of the laws to only firms incorporated in the legislating state.
} 
TABLE 1

State Antitakeover Legislation

\begin{tabular}{|c|c|c|}
\hline Business Combination & Fair Price & Control Share Acquisition \\
\hline Arizona (1987) & Arizona (1987) & Arizona (1987) \\
\hline Connecticut (1989) & Connecticut (1984) & Hawaii (1985) \\
\hline Delaware (1988) & Georgia (1985) & Idaho (1988) \\
\hline Georgia (1988) & Idaho (1988) & Indiana (1986) \\
\hline Idaho (1988) & Illinois (1984) & Kansas (1988) \\
\hline Illinois (1989) & Indiana (1986) & Louisiana (1987) \\
\hline Indiana (1986) & Kentucky (1989) & Maryland (1988) \\
\hline Kansas (1989) & Louisiana (1985) & Massachusetts (1987) \\
\hline Kentucky (1987) & Maryland (1983) & Michigan (1988) \\
\hline Maine (1988) & Michigan (1984) & Minnesota (1984) \\
\hline Maryland (1989) & Mississippi (1985) & Mississippi (1991) \\
\hline Massachusetts (1989) & Missouri (1986) & Missouri (1984) \\
\hline Michigan (1989) & New Jersey (1986) & Nebraska (1988) \\
\hline Minnesota (1987) & New York (1985) & Nevada (1987) \\
\hline Missouri (1986) & North Carolina (1987) & North Carolina (1987) \\
\hline Nebraska (1988) & Ohio (1990) & Oklahoma (1987) \\
\hline Nevada (1991) & Pennsylvania (1989) & Oregon (1987) \\
\hline New Jersey (1986) & South Carolina (1988) & Pennsylvania (1989) \\
\hline New York (1985) & South Dakota (1990) & South Carolina (1988) \\
\hline Oklahoma (1991) & Tennessee (1988) & South Dakota (1990) \\
\hline Ohio $(1990)$ & Virginia (1985) & Tennessee (1988) \\
\hline Pennsylvania (1989) & Washington (1990) & Utah (1987) \\
\hline Rhode Island (1990) & Wisconsin (1985) & Virginia (1988) \\
\hline South Carolina (1988) & & Wisconsin (1991) \\
\hline South Dakota (1990) & & Wyoming (1990) \\
\hline \multicolumn{3}{|l|}{ Tennessee (1988) } \\
\hline \multicolumn{3}{|l|}{ Virginia (1988) } \\
\hline \multicolumn{3}{|l|}{ Washington (1987) } \\
\hline \multicolumn{3}{|l|}{ Wisconsin (1987) } \\
\hline Wyoming (1989) & & \\
\hline
\end{tabular}

Source. - Annotated State Codes, various states and years.

(see table 1 for a list). ${ }^{8}$ Business combination laws impose a moratorium (three to five years) on specified transactions between the target and a raider holding a specified threshold percentage of stock unless the board votes otherwise before the acquiring person becomes an interested shareholder. Specified transactions include sale of assets, mergers, and business relationships between raider and target. For example, the New York statute prohibits, in addition to any merger and consolidation, the sale, lease, exchange, mortgage, pledge, transfer, or other disposition of the assets of the target company to the interested shareholder. The New York law also forbids the adoption of any plan or proposal for the liquidation or dissolution of the target firm, the reclassification of se-

${ }^{8}$ Other (non-business combination) takeover laws are described in Bertrand and Mullainathan $(1999 b)$. These other laws are thought to be, at best, marginally effective. Event study evidence has borne out this belief, showing that business combination laws resulted in the biggest stock price drop (Karpoff and Malatesta 1989). We also have replicated the analysis below for these other laws and also found little effect. 
curities, and the receipt by the interested shareholder of financial assistance (loans, advances, guarantees, or pledges) from the target company.

\section{A. Antitakeover Laws as a Source of Variation in Corporate Governance}

Business combination laws are likely to have strong effects on disciplinary takeovers because they place in the directors' hands, before the acquiring person becomes an interested shareholder, the right to refuse such transactions and because incumbent management greatly influences the board. Barring these transactions impedes highly leveraged takeovers, a trademark of the 1980s, since they are often financed by selling some of the target's assets. In essence, business combination laws give management the right to "veto" a takeover by making it more difficult to finance. ${ }^{9}$

The legal rulings also generally reflect the idea that business combination laws tip the balance of power toward management. In Amanda Acquisition Corp. v. Universal Food Corp., a landmark case on business combination legislation, the court ruled that business combination laws violated management-shareholder neutrality by favoring management. But the ruling went on to state that this violation was not grounds for overturning the law. As another example, Justice Schwartz, deciding on the Delaware business combination law, concluded that it altered the balance of power between management and raider, "perhaps significantly" (see Sroufe and Gelband 1990). As one commentator noted, an implication of the Wisconsin decision was that "the Seventh Circuit's Amanda opinion asserts that a law, such as Wisconsin's business combination statute, can be both economic folly and constitutional" (New York Law Journal, September 14, 1989, p. 5). In short, these laws apparently gave management the power (through the board) to impede hostile takeovers and effectively weakened corporate governance.

\section{B. Political Economy of Laws}

Romano (1987) has investigated the political context in which state antitakeover laws were passed. One important finding of her work is that the passage of these laws typically did not result from the pressures of a large coalition of economic players in the state. Using the Connecticut law as a case study, she concludes that "the spur behind the passage of the Connecticut statute was not a broad-based political co-

\footnotetext{
${ }^{9}$ Some states have specific "opt-out" provisions allowing firms to decide not to be protected by the statute. Because opting out, very much like adopting a poison pill, is potentially endogenous to the economic prospects of the firm, we decided not to exploit this additional feature of the laws in the empirical test below.
} 
alition. Rather, the bill was promoted by a corporation incorporated in Connecticut, the Aetna Life and Casualty Insurance Company (Aetna), which enlisted the support of the most important business association in the state, the Connecticut Business and Industry Association (CBIA)" (pp. 122-23). In many cases, the bills were lobbied for even more exclusively. The Arizona statute, for example, was called the "Greyhound Bill" since it was all but written by Greyhound executives. Typically, the corporation lobbying in favor of the law perceived a takeover threat and pushed for the protective statute to be adopted, often during emergency sessions. Thus, even though we shall directly deal with the possible endogeneity of the laws in the empirical analysis below, the exclusive nature of the lobbying process should already weaken that concern.

\section{Evidence on the Impact of Laws}

Anecdotal evidence on the importance of the state antitakeover laws is plentiful. A mass of cases often followed each law in which raiders attempted to argue against the law. ${ }^{10}$ This indicates that target companies understood the laws well enough to use them as defenses and that raiders felt the laws were a large enough deterrent to success to challenge them in court. Moreover, these laws received extensive coverage by both the popular press and legal practitioners. More systematic empirical work also confirms that the state antitakeover laws had a real bite. Research work on these laws typically falls under three categories: studies of their impact on stock prices, studies of their impact on the number of takeovers, and studies of their impact on various corporate variables.

Several papers have attempted to establish the effect of these laws on stock prices (e.g., Block, Barton, and Roth 1986; Pound 1987; Romano 1987; Schumann 1988; Karpoff and Malatesta 1989; Margotta, McWilliams, and McWilliams 1990; Szewczyk and Tsetsekos 1992). Most papers focus on a single law and use an event study methodology. Many find negative share price effects, some find insignificant negative share price effects, and a few find no share price effect at all. The main difficulty these papers face is choosing the date at which the effect of these laws should be impounded into prices since information about new legislation can be incorporated into expectations and stock prices before it is formally revealed. Some papers use dates of passage of the law, some use dates of the first press announcement, and some use dates

\footnotetext{
${ }^{10}$ New Jersey's law, e.g., was tried in Bilzerian Partners, Ltd. v. Singer Co., no. 87-4363 (D.N.J. December 2, 1987). Delaware's law was immediately challenged in Black \& Decker Corp. v. American Standard Inc., 679 F. Supp. 422 (D.Del. 1988) and CRTF Corp. v. Federated Dept. Stores, Inc., 683 F. Supp. 422 (S.D.N.Y. 1988). Courts consistently found the laws applicable. See Matheson and Olson (1991) for more details.
} 
of the introduction of the law. As a rule, the papers that find the most negative impacts on stock price use press announcements (see Pound 1987; Karpoff and Malatesta 1989; Szewczyk and Tsetsekos 1992). Choosing a specific treatment date is less of an issue in this paper since most of the variables we consider are reported and sometimes decided on annually.

Easterbrook and Fischel (1991) summarize the literature on stock price reactions up to that date. They argue that the value of firms covered by these laws fell, on average, by 0.5 percent. In dollar terms, these are quite large losses. Applied to the entire New York Stock Exchange, they imply a loss of \$10-\$20 billion. Karpoff and Malatesta (1989) examine stock price reactions to all laws passed before 1987. They choose the effective date to be the first date on which they find a press announcement for the law. Their study is useful because they comprehensively analyze each type of law. They find significant negative reactions to the passage of business combination laws only, resulting in a decline in value of approximately 0.467 percent. These negative stock price reactions strongly suggest that the antitakeover legislation had effects beyond the menu of takeover defenses (e.g., poison pills, supermajority rules, or staggered boards) available to management.

One would think that the most direct evidence would come from examining the impact of these laws on actual takeovers. In reality, this is more problematic than other pieces of evidence for two reasons. First, the incidence of hostile takeovers can be quite hard to measure. Since these (and not general mergers and acquisitions) are the ones that discipline management, proper separation of hostile takeovers from nonhostile ones is essential. Second, by many crude proxies, the actual number of such hostile takeovers can be quite small, making inferences difficult. Nevertheless, two papers have attempted this exercise. Hackl and Testani (1988) perform a straightforward differences-in-differences analysis for laws up to 1988 and find that these laws lessen takeover activity. States passing laws experienced approximately a 48 percent smaller rise in takeover attempts in this period. They also find that the proportion of takeover attempts using tender offers went down, as well as the number of tender offer attempts that were successful. On the other hand, Comment and Schwert (1995) find little evidence that antitakeover laws reduce the frequency of takeover activities. However, Comment and Schwert do report that takeover premia went up after the passage of these laws.

Finally, a few papers have examined the impact of these laws on other variables. Garvey and Hanka (1999) find that firms covered by the second generation of state antitakeover laws substantially reduced their leverage ratios. Bertrand and Mullainathan (1999b) provide some first evidence on the impact of the state antitakeover laws on wages. Using 
Compustat as a source of labor data, they find that, relative to a control group, annual wages for firms incorporated in legislating states rose by 1-2 percent. The main difficulty with this result is the extreme noisiness of the Compustat wage data. Bertrand and Mullainathan (1999a) also investigate the impact of the laws on top executives' compensation. They find that mean CEO compensation increased in the protected firms (again relative to a control group). They also show that this effect is stronger among the firms that do not have large block holders sitting on the board of directors. As a whole, the existing literature suggests through both anecdotes and statistical evidence that antitakeover legislation likely impeded the threat of a hostile takeover.

\section{Data}

\section{A. Data Sources}

The main data source used in this paper is a match between the Longitudinal Research Datafile, provided by the Bureau of the Census, and Compustat, provided by Standard and Poor's. The LRD is a large probability sample of plant-level data in the U.S. manufacturing sector. A plant, or establishment, is defined as a separate physical location involved in manufacturing activity. Each plant in the LRD is assigned a unique and time-invariant identifier. The LRD contains historical data from the quinquennial Census of Manufactures and from the Annual Survey of Manufactures (ASM). The Bureau of the Census conducts the Census of Manufactures for the entire universe of manufacturing plants every five years. The ASM is conducted annually but samples only a subset of plants. Each ASM is structured as a panel that starts two years after a Census of Manufactures and goes on for five years. All large plants (at least 250 workers) are in each ASM panel, whereas plants with five to 249 workers are included in a panel with probabilities that increase with the plant size. While smaller plants are randomly selected for inclusion in a given ASM panel, they are followed in each year of that panel once selected. In addition, new plants are added to an ASM panel each year.

The LRD contains annual information on many plant-level variables that are central to our analysis. More specifically, the LRD contains plantlevel information on employment, working hours, wage bill, total assets, total value of shipments, age of plant, capital expenditures, industrial sector, and location. One noteworthy weakness of the labor market information in the LRD is that it does not include basic demographic variables such as workers' average age, education, and tenure.

Compustat is a data source that reports financial variables for more than 7,500 individual corporations established in the United States (and 
territories) since 1976. The data are drawn from annual reports, 10-K filings, and 10-Q filings and sample large companies with substantial public ownership. Most important for our purposes, Compustat reports information on the state of incorporation of each firm. This information is essential to our analysis since state of incorporation determines which antitakeover legislation (if any) affects each firm.

The original merge of the LRD and Compustat, based on employer identification number and company name, was performed by William Long for the year 1987. Starting with this merge, which covers about 1,000 companies, we produced a match between firm identifiers in the LRD and firm identifiers in Compustat. ${ }^{11}$ We then identified, for all years between 1976 and 1995, all the plants that belonged to one of the Compustat firms. This merge produces a sample of 224,188 plant-year observations. Sample sizes will, however, vary across the different specifications since not all variables are available for all plants and years.

We measure state of incorporation only in 1995. Ideally, we would like state of incorporation in some year before the laws were passed, but Compustat files report only the state of incorporation for the latest available year. Anecdotal evidence, however, indicates that changes in state of incorporation are quite rare (see Romano 1993). To provide further evidence on this, we randomly sampled 200 firms from our panel and checked, using Moody's Industrial Manual, whether they had changed state of incorporation during the sample period. We found only three changes in state of incorporation, all of them to Delaware. All three changes predated the 1988 Delaware antitakeover law by several years.

\section{B. Definition of Variables}

On the basis of the information directly available in the LRD, we construct the following variables of interest. We define average hourly production worker wage as the ratio of the production worker wage bill to production worker hours. We compute capital stock by taking the base year capital stock, adding up reported capital expenditures year by year, and depreciating using the industry-wide deflators in the National Bureau of Economic Research Productivity Database. Return on capital is defined as total value of shipments net of labor and material costs and divided by capital stock.

We define a plant birth as occurring when it is the first year a given plant appears as part of a given firm. A plant birth can occur either because a new plant is constructed or because an existing plant is acquired. We define a plant death as occurring when it is the last year a

\footnotetext{
${ }^{11}$ The LRD is constructed so that fully owned subsidiaries are included in the firm under this identifier.
} 
given plant appears as part of a given firm. A plant death can occur because the plant is either shut down or sold off to another firm.

How does the sampling frame of the LRD affect the measurement of these birth and death variables? Recall that each ASM panel tracks in every year all the plants that were originally sampled for that panel. However, smaller plants may not be sampled for each ASM panel. Since each of these unsampled smaller plants, if alive, will reappear in the next census year, we shall never mislabel an unsampled plant as having died. We can, however, mismeasure the exact year of birth and death of a small plant. For example, if a small unsampled plant dies between two census years, we shall label that plant as having died in the last census year it appears in. This introduces a source of measurement error in the birth and death dummy variables and will add noise to our regressions. There is, however, no reason why this measurement error should induce systematic biases in our findings since all plant births and deaths are eventually correctly accounted for, and only the exact timing of these events might be mismeasured.

\section{Summary Statistics}

Table 2 presents means and standard deviations for the main variables of interest in our sample of plant-year observations. Column 1 reports data for the full sample; the other two break down the data on the basis of whether the plant is incorporated in a state that eventually passes a business combination law (col. 2) or never passes a business combination law (col. 3). All dollar figures are expressed in 1994 dollars.

The average plant in the sample has a total value of shipments of about $\$ 59$ million and employs 436 workers. The average hourly wage for production workers is $\$ 7.60$. The probability of a plant death in a given year is about 9 percent, and the probability of a plant birth is about 6.5 percent. Such high turnover rates are typical in plant-level data (Davis, Haltiwanger, and Shuh 1996). A typical plant belongs to a firm that owns about 45 other plants, and the average firm in the sample has about 12 plants.

The split by "eventually business combination" and "never business combination" makes it clear that passing states contain larger plants and larger firms. For example, the average firm in the eventually business combination group has about 12 plants, whereas the average firm in the never business combination group has only about eight plants. These differences are not the results of the laws as they exist even if one focuses on the period in which no laws have been adopted yet. If plants or firms of different size experience different shocks, one might be concerned that the control group here is not an appropriate one. There are two main reasons why this is not a serious issue. First, it is important to keep 
TABLE 2

Summary Statistics (Plant-Level Data)

\begin{tabular}{|c|c|c|c|}
\hline Variable & $\begin{array}{l}\text { All } \\
(1)\end{array}$ & $\begin{array}{c}\text { Eventually } \\
\text { Business } \\
\text { Combination } \\
\text { (2) }\end{array}$ & $\begin{array}{c}\text { Never } \\
\text { Business } \\
\text { Combination } \\
\text { (3) }\end{array}$ \\
\hline $\begin{array}{l}\text { Total value of } \\
\text { shipments }\end{array}$ & $\begin{array}{c}58,779 \\
(225,681)\end{array}$ & $\begin{array}{c}61,360 \\
(234,442)\end{array}$ & $\begin{array}{c}37,880 \\
(133,435)\end{array}$ \\
\hline $\begin{array}{l}\log (\text { total value of } \\
\text { shipments })\end{array}$ & $\begin{array}{c}9.48 \\
(1.72)\end{array}$ & $\begin{array}{c}9.51 \\
(1.71)\end{array}$ & $\begin{array}{l}9.18 \\
(1.70)\end{array}$ \\
\hline Capital stock & $\begin{array}{c}29,593 \\
(101,576)\end{array}$ & $\begin{array}{c}30,993 \\
(105,165)\end{array}$ & $\begin{array}{c}18,259 \\
(64,536)\end{array}$ \\
\hline Log (capital stock) & $\begin{array}{c}8.01 \\
(1.81)\end{array}$ & $\begin{array}{c}8.04 \\
(1.82)\end{array}$ & $\begin{array}{c}7.73 \\
(1.69)\end{array}$ \\
\hline Blue-collar wage & $\begin{array}{c}7.61 \\
(5.29)\end{array}$ & $\begin{array}{c}7.64 \\
(5.34)\end{array}$ & $\begin{array}{l}7.35 \\
(4.85)\end{array}$ \\
\hline $\begin{array}{l}\text { Log (blue-collar } \\
\text { wage) }\end{array}$ & $\begin{array}{l}1.82 \\
(.67)\end{array}$ & $\begin{array}{l}1.83 \\
(.67)\end{array}$ & $\begin{array}{l}1.79 \\
(.66)\end{array}$ \\
\hline Employment & $\begin{array}{c}436.1 \\
(1,145)\end{array}$ & $\begin{array}{c}454.2 \\
(1,197)\end{array}$ & $\begin{array}{c}289.8 \\
(559.1)\end{array}$ \\
\hline Log(employment) & $\begin{array}{l}5.01 \\
(1.54)\end{array}$ & $\begin{array}{c}5.04 \\
(1.52)\end{array}$ & $\begin{array}{c}4.69 \\
(1.61)\end{array}$ \\
\hline Plant death dummy & $\begin{array}{l}.09 \\
(.29)\end{array}$ & $\begin{array}{l}.09 \\
(.28)\end{array}$ & $\begin{array}{l}.11 \\
(.32)\end{array}$ \\
\hline Plant birth dummy & $\begin{array}{l}.06 \\
(.24)\end{array}$ & $\begin{array}{l}.06 \\
(.24)\end{array}$ & $\begin{array}{l}.08 \\
(.28)\end{array}$ \\
\hline Investment & $\begin{array}{c}5,132 \\
(19,833)\end{array}$ & $\begin{array}{c}5,318 \\
(20,271)\end{array}$ & $\begin{array}{c}3,459 \\
(15,234)\end{array}$ \\
\hline Log(investment) & $\begin{array}{c}6.79 \\
(1.87)\end{array}$ & $\begin{array}{c}6.82 \\
(1.87)\end{array}$ & $\begin{array}{c}6.51 \\
(1.81)\end{array}$ \\
\hline Return on capital & $\begin{array}{l}.21 \\
(.33)\end{array}$ & $\begin{array}{l}.21 \\
(.33)\end{array}$ & $\begin{array}{l}.21 \\
(.35)\end{array}$ \\
\hline Number of plants & $\begin{array}{c}44.5 \\
(44.8)\end{array}$ & $\begin{array}{c}46.0 \\
(45.8)\end{array}$ & $\begin{array}{l}32.3 \\
(32.9)\end{array}$ \\
\hline $\begin{array}{l}\text { Number of plants } \\
\text { (firm-level) }\end{array}$ & $\begin{array}{l}11.5 \\
(19.5)\end{array}$ & $\begin{array}{l}12.1 \\
(20.3)\end{array}$ & $\begin{array}{l}8.14 \\
(14.0)\end{array}$ \\
\hline Observations & 224,188 & 199,511 & 24,677 \\
\hline
\end{tabular}

in mind that, because of the staggering of the different business combination statutes over time, plants in the eventually business combination group are both control and treatment plants. Second, we shall directly investigate the robustness of our results to the possibility that plants (and firms) of different size may be experiencing different shocks. Finally, we shall reestimate all the basic specifications focusing only on the plants and firms in the eventually business combination group. 


\section{Empirical Methodology}

We examine the effect of the takeover legislation using essentially a differences-in-differences methodology. In the firm-level data, the basic regression we estimate is

$$
y_{j k l t}=\alpha_{t}+\alpha_{j}+\gamma X_{j k l t}+\delta B C_{k t}+\epsilon_{j k l v}
$$

where $j$ indexes firms, $k$ indexes state of incorporation, $l$ indexes state of location, $t$ indexes time, $y_{j k l t}$ is the dependent variable of interest (wages, e.g.), $\alpha_{t}$ and $\alpha_{j}$ are year and firm fixed effects, $X_{j k l t}$ are control variables, $B C_{k t}$ is a dummy variable that equals one if an antitakeover law has been passed by time $t$ in state $k$, and $\epsilon_{j k l t}$ is an error term. This methodology fully controls for fixed differences between treated and nontreated firms via the firm fixed effects. ${ }^{12}$ The year dummies control for aggregate fluctuations. Our estimate of the law's effect is $\delta$.

This approach can be easily understood with an example. Suppose that we wish to estimate the effect of the Pennsylvania law passed in 1989 on workers' wages. We would subtract wages after 1989 from wages before 1989 for the Pennsylvania firms. However, other things in 1989, such as a recession, may have affected Pennsylvania firms. Choosing a control state, for example, New Jersey, would help control for changing economic conditions. If New Jersey firms were also subject to this recession, the change in their wages would be a measure of its severity. We would therefore compare the difference in wages in Pennsylvania before and after 1989 to the difference in wages in New Jersey before and after 1989. The difference of those two differences would serve as the estimate of the law's effect in Pennsylvania. One important difference between this example and the regression framework is that the regression accounts for the fact that there are many takeover laws staggered over time. The staggered passage of the antitakeover statutes also means that our control group is not restricted to states that never pass a law. In fact, equation (1) can be estimated even if all states eventually passed a law. It implicitly takes as the control group all firms incorporated in states not passing a law at time $t$, even if they have already passed a law or will pass one later on.

We can improve on this estimation strategy for the plant-level analysis, which constitutes the bulk of our analysis below. The main advantage of using plant-level data is that they allow us to directly address the important issue of changing economic conditions. Indeed, consider the alternative scenario in which we have to rely solely on firm-level data. Because a firm's primary state of location is likely to also be its state of incorporation, it is hard to separate out the effects of local shocks con-

\footnotetext{
${ }^{12}$ Following the experimental terminology, we shall refer to firms and states that are affected by the law as "treated" and unaffected ones as "control."
} 
temporaneous with the law from the effects of the law itself. In other words, if some economic shock were specifically hitting Pennsylvania at the same time it passed its antitakeover law, our estimate of the effect of the laws could be biased. Alternatively, current and future local economic conditions could influence the passage of the laws themselves. For example, local unions could be lobbying in favor of the adoption of antitakeover legislation. If their success in lobbying depends on the tightness of the local labor market at the time, this might lead to a spurious positive correlation between wages and the passage of the business combination laws. Firms with many plants and a large workforce in a given state might also be in a strong bargaining position to influence the adoption of an antitakeover statute by that state. These firms might be in an especially strong position if their future growth prospects in that state are high. ${ }^{13}$

Plant-level data allow us to control for such changing local conditions for two reasons. First, the data set gives us information about plants that are located in Pennsylvania (as in the example above) but are incorporated elsewhere. Second, it gives us information about plants located outside of Pennsylvania but incorporated there. More generally, the incomplete congruence between incorporation and location in the plant-level data allows us in theory to fully control for shocks to state of location by adding a full set of state of location dummies interacted with year dummies, $\alpha_{l} \times \alpha_{t}$. In practice, computational difficulties make it infeasible to run a specification that includes the full set of $\alpha_{l} \times \alpha_{t}$ dummies. Instead, we include as a control the mean value of the dependent variable in state of location $l$ and year $t$ (excluding plant $i$ itself from the mean), $y_{t t(-i)}$ :

$$
y_{i j k l t}=\alpha_{t}+\alpha_{i}+\alpha_{k}+\gamma X_{i j k l t}+\rho y_{l t(-i)}+\delta B C_{k t}+\epsilon_{i j k l t}
$$

where $i$ indexes plants, $\alpha_{i}$ are plant fixed effects, $\alpha_{k}$ are state of incorporation fixed effects, and all the variables are defined as above.

Note that this specification controls for both plant and state of incorporation fixed effects since a given plant may change ownership and thus possibly state of incorporation over time. ${ }^{14}$

The only major concern that is not directly dealt with in this plantlevel approach is the possibility that lobbying occurs at the level of the state of incorporation, not state of location, and that the success in

\footnotetext{
${ }^{13}$ As we mentioned earlier, existing studies on the political economy of the takeover statutes suggest that such broad-based lobbying was not the norm.

${ }^{14} \mathrm{~A}$ possible modification of our empirical strategy would be to focus only on firms that are under threat of a hostile takeover (or perhaps interact $B C_{k t}$ with a continuous probability of takeover). We were unable to find an effective way to do this because of the difficulty in predicting who will be the target of a hostile takeover. Simply using raw takeover probabilities would be misleading since many takeovers are not hostile, and it is only the hostile ones that are relevant for our purposes.
} 
getting the statutes adopted directly depends on commonly changing economic prospects for the firms lobbying together. Hence our findings might be spurious if a large coalition of managers whose firms are incorporated in the same state and are experiencing, for example, increasing wages and declining productivity at the same time are more likely to successfully lobby for the adoption of takeover laws in their state of incorporation. We find such a story unconvincing because of Romano's (1987) evidence of a very exclusive political process, where the takeover statutes are often passed under the political pressure of a single company. Nevertheless, we directly address this concern below by investigating the dynamic effects of the antitakeover laws. If the laws were passed in response to changing economic conditions, one might expect an "effect" of the laws even prior to their passage. As we shall see, we do not find such spurious effects. This again suggests that this political economy channel does not drive our results.

\section{Results}

A. Wages

There are several reasons to believe that managers may prefer to pay higher wages than profit-maximizing shareholders do. For example, empire-building managers might care more than owners about the prestige of being surrounded by high-quality workers. High wages can also make a manager's job easier by reducing turnover, reducing the need for bargaining effort in a union context, or simply buying "peace" from the workers. More broadly, managers might care more than owners about improving workplace relations since they are the ones who endure the workers' complaints and enjoy the workers' company. Popular accounts of raiders raiding firms support this idea, suggesting that some of the gains of a takeover come from reducing the high wages produced by the previously bad management. Rosett (1990) calculates that a substantial portion of the gains from a takeover can be attributed to a reduction in wages.

In table 3, we systematically investigate the relevance of these arguments by studying the effect of the business combination legislation on production worker wages. The estimated coefficient of interest is the one on $B C$, a dummy variable that equals one if a business combination statute has been passed in the state of incorporation of the firm a given plant belongs to. All the regressions reported in this table include year fixed effects, state of incorporation fixed effects, and plant fixed effects. Also, in this table and all following tables, we allow for clustering of the observations at the state of location level to account for the presence 
TABLE 3

Effects of Business Combination Laws on Blue-Collar Wages $(N=191,211)$

\begin{tabular}{|c|c|c|c|c|c|}
\hline & & DEPEND & VARIABLF & (WAGE) & \\
\hline & (1) & (2) & (3) & (4) & (5) \\
\hline$B C$ & $\begin{array}{l}.013 \\
(.005)\end{array}$ & $\begin{array}{l}.013 \\
(.005)\end{array}$ & $\begin{array}{l}.013 \\
(.005)\end{array}$ & $\begin{array}{l}.012 \\
(.005)\end{array}$ & $\ldots$ \\
\hline State-year & $\ldots$ & $\begin{array}{l}.436 \\
(.013)\end{array}$ & $\begin{array}{l}.436 \\
(.061)\end{array}$ & $\begin{array}{l}.436 \\
(.061)\end{array}$ & $\begin{array}{l}.439 \\
(.062)\end{array}$ \\
\hline $\log ($ age $)$ & $\ldots$ & $\ldots$ & $\begin{array}{l}.037 \\
(.005)\end{array}$ & $\begin{array}{l}.038 \\
(.005)\end{array}$ & $\ldots$ \\
\hline Return on capital & $\ldots$ & $\ldots$ & $\begin{array}{c}-.001 \\
(.000)\end{array}$ & $\begin{array}{l}-.001 \\
(.000)\end{array}$ & $\ldots$ \\
\hline $\log ($ employment $)$ & $\ldots$ & $\ldots$ & $\begin{array}{l}-.016 \\
(.003)\end{array}$ & $\ldots$ & $\ldots$ \\
\hline Before $^{-1}$ & $\ldots$ & $\ldots$ & $\ldots$ & $\ldots$ & $\begin{array}{l}.004 \\
(.004)\end{array}$ \\
\hline Before $^{0}$ & $\ldots$ & $\ldots$ & $\ldots$ & $\ldots$ & $\begin{array}{l}.009 \\
(.004)\end{array}$ \\
\hline After $^{1}$ & $\ldots$ & $\ldots$ & $\ldots$ & $\ldots$ & $\begin{array}{l}.015 \\
(.006)\end{array}$ \\
\hline After $^{2+}$ & $\ldots$ & $\ldots$ & $\ldots$ & $\ldots$ & $\begin{array}{l}.019 \\
(.007)\end{array}$ \\
\hline $\begin{array}{l}\text { Plant fixed effects? } \\
\text { State of incorporation }\end{array}$ & yes & yes & yes & yes & yes \\
\hline fixed effects? & yes & yes & yes & yes & yes \\
\hline Year fixed effects? & yes & yes & yes & yes & yes \\
\hline $\begin{array}{l}\log (\text { base year employ- } \\
\text { ment) } \times \text { year fixed } \\
\text { effects? } \\
R^{2}\end{array}$ & $\begin{array}{l}\text { no } \\
.836\end{array}$ & $\begin{array}{l}\text { no } \\
.836\end{array}$ & $\begin{array}{l}\text { no } \\
.836\end{array}$ & $\begin{array}{l}\text { yes } \\
.836\end{array}$ & $\begin{array}{l}\text { no } \\
.836\end{array}$ \\
\hline $\begin{array}{l}\text { NOTE.-The dependent varia } \\
\text { Compustat match for the years } \\
\text { been passed. State-year refers } \\
\text { (excluding the plant itself). Be } \\
\text { will pass business combination } \\
\text { incorporated in a state that pass } \\
\text { if the plant is incorporated in } \\
\text { variable that equals one if the } \\
\text { ago or more. Standard errors ( } \\
\text { level. }\end{array}$ & $\begin{array}{l}\text { og of } \\
C \text { is a } \\
\text { log } \\
\text { lumn } \\
\text { in or } \\
\text { comb } \\
\text { passe } \\
\text { rpor } \\
\text { ces) }\end{array}$ & $\begin{array}{l}\text { on work } \\
\text { ariable t } \\
\text { on worke } \\
\text { that eq } \\
\text { efore is is } \\
\text { gislation } \\
\text { s combir } \\
\text { state tha } \\
\text { ted for c }\end{array}$ & $\begin{array}{l}\text { Plant-le } \\
\text { Is one if } \\
\text { in the pla } \\
\text { if the pla } \\
\text { my variab } \\
\text { r. After is } \\
\text { gislation } \\
\text { business } \\
\text { of the o }\end{array}$ & $\begin{array}{l}\text { ire take } \\
\text { combi } \\
\text { of loca } \\
\text { orporat } \\
\text { quals or } \\
\text { y variab } \\
\text { ago. Af } \\
\text { tion leg }\end{array}$ & $\begin{array}{l}\text { the LRD- } \\
\text { atute has } \\
\text { that year } \\
\text { state that } \\
\text { plant is } \\
\text { quals one } \\
\text { a dummy } \\
\text { two years } \\
\text { location }\end{array}$ \\
\hline
\end{tabular}

of serial correlation in the data (see Bertrand, Duflo, and Mullainathan 2002). ${ }^{15}$

Column 1 of table 3 estimates the basic impact of the state laws on the mean wage of production workers in a protected plant. Mean bluecollar wages significantly go up by 1.3 percent after the business combination laws are passed. We investigate the robustness of this wage effect in the rest of the table. First, we control for state of location-specific shocks. In column 2 , we include mean wage in the state of location of

${ }^{15}$ In regressions not reported here, we also allowed for correlated error terms at the state of incorporation level and found similar results. 
the plant. ${ }^{16}$ The point estimate for the wage effect of the business combination laws remains unchanged (1.3 percent). We maintain this control for state of location-specific shocks in all the other specifications in this table. In column 3, we show that the wage effect is robust to the inclusion of other plant-specific controls: age of plant, return on capital, and employment. Because such controls are likely endogenous to the legislative changes, we prefer not to include them in our basic specification but rather verify that our results are not qualitatively affected by their inclusion. Not surprisingly, we find that older plants are associated with higher wages. We also find a negative relationship between wages and return on capital and employment. The estimated negative relationship between wages and return on capital in this ordinary least squares model is consistent with previous work and captures the negative mechanical relationship between labor income and capital income. The negative relationship between wages and employment likely reflects a division bias since wages were computed as the ratio of the wage bill to production hours in a plant. ${ }^{17}$ In column 4 , we allow for the time shocks to differentially affect plants of different size. We interact the full set of year dummies with base year plant employment. Again, the estimated coefficient on the $B C$ dummy is unaffected.

In column 5, we further investigate issues of reverse causality and political economy that may be especially important for wages given workers' and unions' lobbying power. As we explained at length before, such issues are very much minimized in this paper given that the laws are based on a plant's state of incorporation, not state of location, and that we can control for shocks to state of location in the plant-level data. This takes care of the possibility that, for example, a business combination statute is more likely adopted by a state when local unions are getting stronger and exerting upward pressures on wages. An alternative way to address reverse causality issues is to study in greater detail the dynamic effects of the business combination legislation on wages. In practice, in column 5, we replace the $B C$ dummy with four dummy variables: before ${ }^{-1}$ is a dummy variable that equals one for a plant that is incorporated in a state that will adopt business combination legislation one year prior to passage of that legislation, before ${ }^{0}$ is a dummy variable that equals one for a plant that is incorporated in a state that passes business combination legislation in that year, after ${ }^{1}$ is a dummy variable that equals one for a plant that is incorporated in a state that passed business combination legislation last year, and $\mathrm{after}^{2+}$ is a dummy var-

\footnotetext{
${ }^{16}$ Remember that when computing those state-year cell means, we always exclude the plant itself.

${ }^{17}$ When we use the logarithm of the total value of shipment as an alternative measure of plant size, we find a positive coefficient, more consistent with the usual firm size wage effect. The coefficient on $B C$ stays unchanged.
} 
iable that equals one for a plant that is incorporated in a state that passed business combination legislation at least two years ago. The dummy variable before ${ }^{-1}$ allows us to assess whether any wage effect can be found prior to the introduction of the business combination legislation. Finding such an "effect" of the legislation prior to its introduction could be symptomatic of some reverse causation. In fact, the estimated coefficient on before ${ }^{-1}$ is economically and statistically insignificant. Interestingly, and also consistent with a causal interpretation of our basic result, we find that the estimated coefficient on the before ${ }^{0}$ dummy is economically smaller than those on the after ${ }^{1}$ and (especially) after ${ }^{2+}$ dummies.

The results above focus solely on blue-collar workers. Indeed, the LRD does not provide an ideal data source to study white-collar workers since it covers only a small and nonrepresentative sample of such workers: those working in manufacturing plants. Therefore, we briefly turn to another data set, the Census of Auxiliary Establishments, which collects data on head offices and other administrative and service-related establishments.

By its very nature, the Census of Auxiliary Establishments contains a much larger and much more representative sample of white-collar workers. There are, however, several weaknesses to this data set. First, the data have been collected for only four different years over the period under study: 1977, 1982, 1987, and 1992. This restricts our ability to account for any time trend in wages or to study the exact dynamics of the wage effect (as we did for blue-collar workers' wages). Second, we observe neither office identifiers nor the state of location of the offices. We can match the offices only to a given firm. This obviously prevents us from accounting for shocks to white-collar wages that are specific to the state of location.

Keeping these data limitations in mind, we document in table 4 the impact of the business combination legislation on white-collar workers. In columns 1 and 2, the dependent variable is the logarithm of the average wage in a given office. The specifications in both columns 1 and 2 include year fixed effects and firm fixed effects in addition to the $B C$ dummy. Column 2 also controls for the logarithm of the firm total value of shipments. Consistent with our intuition, we find an effect of the business combination statutes on white-collar wages that is both statistically significant and larger than the effect for blue-collar workers. Wages in auxiliary offices appear to go up by as much as 4 percent after the passage of the antitakeover legislation.

Note that employment in auxiliary offices also appears to go up after the business combination laws are passed (cols. 3 and 4). The effect is large. This is the only form of active empire building we find evidence for in this paper. While we shall find in the next section no sign of 
TABLE 4

Effects of Business Combination Laws on White-Collar Workers $(N=35,830)$

\begin{tabular}{|c|c|c|c|c|}
\hline & \multicolumn{4}{|c|}{ DePendent Variable } \\
\hline & \multicolumn{2}{|c|}{ Log(Wage) } & \multicolumn{2}{|c|}{ Log(Employment) } \\
\hline & (1) & (2) & (3) & (4) \\
\hline$B C$ & $\begin{array}{l}.044 \\
(.013)\end{array}$ & $\begin{array}{l}.038 \\
(.013)\end{array}$ & $\begin{array}{l}.110 \\
(.045)\end{array}$ & $\begin{array}{l}.084 \\
(.045)\end{array}$ \\
\hline $\begin{array}{l}\log \text { (total value } \\
\text { of shipment) }\end{array}$ & $\cdots$ & $\begin{array}{l}.012 \\
(.005)\end{array}$ & $\cdots$ & $\begin{array}{l}.048 \\
(.017)\end{array}$ \\
\hline $\begin{array}{l}\text { Firm fixed } \\
\text { effects? } \\
\text { Year fixed }\end{array}$ & yes & yes & yes & yes \\
\hline $\begin{array}{l}\text { effects? } \\
R^{2}\end{array}$ & $\begin{array}{l}\text { yes } \\
.412\end{array}$ & $\begin{array}{l}\text { yes } \\
.412\end{array}$ & $\begin{array}{l}\text { yes } \\
.282\end{array}$ & $\begin{array}{l}\text { yes } \\
.282\end{array}$ \\
\hline
\end{tabular}

increased investment either through the creation of new operating plants or through extensions of existing operations, top managers do appear to benefit from a very special form of company growth: a large and very well paid white-collar staff.

\section{B. Death, Birth, and Investment}

There are three forms of investment that can be measured in our data set: the creation of a new plant, the destruction of an old plant, and capital expenditures in existing plants. In this subsection, we investigate how these three investment margins are affected by the passage of the antitakeover legislation.

In table 5, we focus on the probability of plant death. Each regression in table 5 includes year fixed effects and firm fixed effects. Column 1 displays the result of a basic linear probability specification. We find that the probability of a plant death is about 2 percent lower among the protected plants. Since the average plant death rate was about 9 percent per year, this is quite a large effect. In column 2, we account for state of location-specific shocks that might be correlated with the passage of the business combination laws. We control for the mean rate of plant deaths in the state of location-year cell, excluding the plant itself from the mean. The results are unchanged. ${ }^{18}$ In column 3, we further control for plant age, return on capital, and plant-level employment. As expected, older, lower-profitability, and lower-employment plants are more likely to disappear. Accounting for these additional, but

${ }^{18}$ We have also experimented with controlling for the mean level of plant deaths in the industry-year cell in order to capture industry-specific shocks. This did not affect the basic result either. 
TABLE 5

Effects of Business Combination Laws on Plant Deaths

\begin{tabular}{|c|c|c|c|c|c|c|}
\hline & \multicolumn{6}{|c|}{ Dependent Variable: Death Dummy } \\
\hline & \multicolumn{5}{|c|}{ Linear Probability Model } & \multirow{2}{*}{$\begin{array}{l}\text { Probit } \\
\text { Probability } \\
\text { Model } \\
(6)\end{array}$} \\
\hline & $(1)$ & $(2)$ & (3) & (4) & $(5)$ & \\
\hline$B C$ & $\begin{array}{c}-.025 \\
(.003)\end{array}$ & $\begin{array}{c}-.025 \\
(.003)\end{array}$ & $\begin{array}{c}-.023 \\
(.004)\end{array}$ & $\begin{array}{c}-.021 \\
(.002)\end{array}$ & $\ldots$ & $\begin{array}{c}-.021 \\
(.002)\end{array}$ \\
\hline State-year & $\ldots$ & $\begin{array}{l}.329 \\
(.038)\end{array}$ & $\begin{array}{l}.244 \\
(.027)\end{array}$ & $\begin{array}{c}.272 \\
(.030)\end{array}$ & $\begin{array}{l}.329 \\
(.038)\end{array}$ & $\begin{array}{l}.311 \\
(.033)\end{array}$ \\
\hline $\log ($ age $)$ & $\cdots$ & $\ldots$ & $\begin{array}{l}.006 \\
(.002)\end{array}$ & $\begin{array}{l}.000 \\
(.002)\end{array}$ & $\ldots$ & $\ldots$ \\
\hline Return on capital & $\cdots$ & $\cdots$ & $\begin{array}{c}-.004 \\
(.000)\end{array}$ & $\begin{array}{c}-.004 \\
(.000)\end{array}$ & $\cdots$ & $\cdots$ \\
\hline $\log ($ employment $)$ & $\cdots$ & $\cdots$ & $\begin{array}{c}-.042 \\
(.000)\end{array}$ & $\ldots$ & $\cdots$ & $\cdots$ \\
\hline Before $^{-1}$ & $\cdots$ & $\ldots$ & $\ldots$ & $\cdots$ & $\begin{array}{c}.007 \\
(.006)\end{array}$ & $\ldots$ \\
\hline Before $^{0}$ & $\ldots$ & $\ldots$ & $\ldots$ & $\ldots$ & $\begin{array}{c}-.011 \\
(.005)\end{array}$ & $\cdots$ \\
\hline After $^{1}$ & $\cdots$ & $\ldots$ & $\cdots$ & $\cdots$ & $\begin{array}{c}-.024 \\
(.005)\end{array}$ & $\cdots$ \\
\hline After $^{2+}$ & $\ldots$ & $\ldots$ & $\ldots$ & $\cdots$ & $\begin{array}{c}-.035 \\
(.004)\end{array}$ & $\ldots$ \\
\hline Firm fixed effects? & yes & yes & yes & yes & yes & yes \\
\hline Year fixed effects? & yes & yes & yes & yes & yes & yes \\
\hline $\begin{array}{l}\log \text { (base year em- } \\
\text { ployment) } \times \text { year } \\
\text { fixed effects? }\end{array}$ & no & no & no & yes & no & no \\
\hline$R^{2}$ & .065 & .071 & .099 & .086 & .066 & .042 \\
\hline Observations & 225,231 & 225,231 & 191,439 & 191,439 & 225,231 & 225,231 \\
\hline
\end{tabular}

NoTE. - The dependent variable is a dummy that equals one in the plant's last year of existence. Plant-level data are taken from the LRD-Compustat match for the years 1976-95. $B C$ is a dummy variable that equals one if a business combination statute has been passed. State-year refers to the mean of the dependent variable in the plant's state of location in that year (excluding the plant itself). See the note to table 3 for a description of the other variables. The reported coefficient in the probit model is the effect of a marginal change in the corresponding variable on the probability of plant death, computed at the sample mean of the independent variable. Standard errors (in parentheses) are corrected for clustering of the observations at the state of location level.

likely endogenous, controls, however, does not affect the estimated negative effect of the business combination laws on the probability of plant death. Similarly, allowing for differential time shocks by plant-level base year employment (col. 4) leaves the main result unaffected.

In column 5, we investigate the dynamic effect of the business combination laws on the probability of plant death. As before, we replace the single $B C$ dummy with four dummy variables to track the effect of the laws "before" and after passage: before ${ }^{-1}$, before ${ }^{0}$, after $^{1}$, and after $^{2+}$. Consistent with a causal interpretation, the estimated coefficient on the before $^{-1}$ dummy variable is economically small and statistically insignificant. Also, the estimated effect of the business combination laws the year of passage, before ${ }^{0}$, while already negative and significant, is smaller 
TABLE 6

Effects of Business Combination Laws on Plant Births $(N=225,231)$

\begin{tabular}{|c|c|c|c|c|c|}
\hline & \multicolumn{5}{|c|}{ Dependent Variable: Birth Dummy } \\
\hline & \multicolumn{4}{|c|}{ Linear Probability Model } & \multirow{2}{*}{$\begin{array}{c}\text { Probit } \\
\text { Probability } \\
\text { Model } \\
(5)\end{array}$} \\
\hline & (1) & (2) & (3) & (4) & \\
\hline$B C$ & $\begin{array}{c}-.019 \\
(.004)\end{array}$ & $\begin{array}{c}-.019 \\
(.004)\end{array}$ & $\begin{array}{c}-.020 \\
(.004)\end{array}$ & $\ldots$ & $\begin{array}{c}-.008 \\
(.002)\end{array}$ \\
\hline State-year & $\ldots$ & $\begin{array}{c}.391 \\
(.063)\end{array}$ & $\begin{array}{l}.360 \\
(.059)\end{array}$ & $\begin{array}{c}.390 \\
(.063)\end{array}$ & $\begin{array}{l}.156 \\
(.023)\end{array}$ \\
\hline Before $^{-1}$ & $\ldots$ & $\ldots$ & $\ldots$ & $\begin{array}{c}.017 \\
(.004)\end{array}$ & $\ldots$ \\
\hline Before $^{0}$ & $\ldots$ & $\ldots$ & $\ldots$ & $\begin{array}{c}-.014 \\
(.004)\end{array}$ & $\ldots$ \\
\hline After $^{1}$ & $\cdots$ & $\ldots$ & $\cdots$ & $\begin{array}{c}-.014 \\
(.007)\end{array}$ & $\cdots$ \\
\hline After $^{2+}$ & $\ldots$ & $\ldots$ & $\ldots$ & $\begin{array}{c}-.015 \\
(.004)\end{array}$ & $\ldots$ \\
\hline Firm fixed effects? & yes & yes & yes & yes & yes \\
\hline Year fixed effects? & yes & yes & yes & yes & yes \\
\hline $\begin{array}{l}\log (\text { base year firm } \\
\text { employment }) \\
\text { x year fixed }\end{array}$ & & & & & \\
\hline effects? & no & no & yes & no & no \\
\hline$R^{2}$ & .084 & .086 & .090 & .086 & .086 \\
\hline
\end{tabular}

than the estimated effects one year, and especially two years or more, after passage.

Finally, we have also checked the sensitivity of this result to alternative probability estimation models. Column 6 uses a probit model and finds similar evidence of a drop in plant deaths following the laws. A logit model (not reported here) delivers a similar result.

Table 6 replicates table 5 but concentrates on episodes of plant births rather than plant deaths. Again, each regression controls for firm fixed effects and year fixed effects. Using a linear probability model, we find that the probability of plant birth goes down by about 2 percent after the passage of the laws (col. 1). Relative to a plant creation rate of nearly 7 percent per year, this effect is quite large. Controlling for the mean rate of plant creation in the state of location-year cell (col. 2) does not alter this finding. Similarly, this effect is robust to allowing for differential time shocks by firm size (col. 3). A study of the dynamic effects of the legislation (col. 4) indicates that there is no sign of a decline in plant births the year prior to the passage of the legislation. In fact, the 
estimated coefficient on the before ${ }^{-1}$ dummy is positive. Finally, we have also verified that this finding is qualitatively robust to other (nonlinear) probability models, such as probit and logit. In the probit model reported in column 5, we estimate that the probability of plant birth goes down by about 1 percent following the passage of the antitakeover laws.

Tables 5 and 6 show that the weakening of corporate governance leads to drops in both plant creation and destruction. A logical implication of our findings in tables 5 and 6 is that the average age of the capital stock in the protected firms must have gone up relative to a control group. We checked that this implication holds true in the data. Age of plants in the affected companies indeed rose significantly.

One might worry about possible confounding effects in these regressions. To be specific, it might be that it is not the threat of takeover but actual takeover reduction that generates these findings. This could clearly explain the reduction in plant deaths. If firms tend (for some unspecified reason) to take over other firms incorporated in the same state, this could in principle also explain the reduction in plant births. To investigate this possibility, we further decomposed the birth and death variables. For birth, we created two dummies, one for whether the plant was acquired and one for whether the plant was built. The sum of these two dummies equals the birth dummy since every born plant must be either built or acquired. For deaths, we created one dummy for whether the plant was shut down and one for whether the plant was sold off. Again, the sum of these two dummies equals the death dummy since every dying plant must be either shut down or sold off. We then replicated the specifications in tables 5 and 6 for each of these dummy variables separately. We found as much of a decline in births due to new constructions as due to acquisitions, and nearly as much of a decline in deaths due to shutdowns as due to sales. ${ }^{19}$ As might have been expected from the sheer magnitude of the effects in tables 5 and 6 , this suggests that the mechanical effect of the reduction in takeover activity cannot solely explain the birth and death findings.

We now turn in table 7 to the effect of the business combination law on plant-level capital expenditures. Sample sizes are substantially smaller here because the capital expenditures variable is available for only a limited subset of the plants in the original sample. Column 1 presents the basic specification in which we control for year, plant, and state of incorporation fixed effects. The point estimate on the treatment coefficient $B C$ is economically small and statistically insignificant. The same holds when we further control the mean level of investment in the state

\footnotetext{
${ }^{19}$ In basic specifications including firm and year fixed effects, the estimated coefficients on the $B C$ dummy were as follows: startup dummy, -.01 ; acquisition dummy, -.01 ; shutdown dummy, -.01 ; and sale dummy, -.02 . All these coefficients were statistically significant at the 1 percent level.
} 
TABLE 7

Effects of Business Combination Laws on Plant-Level Investment $(N=110,204)$

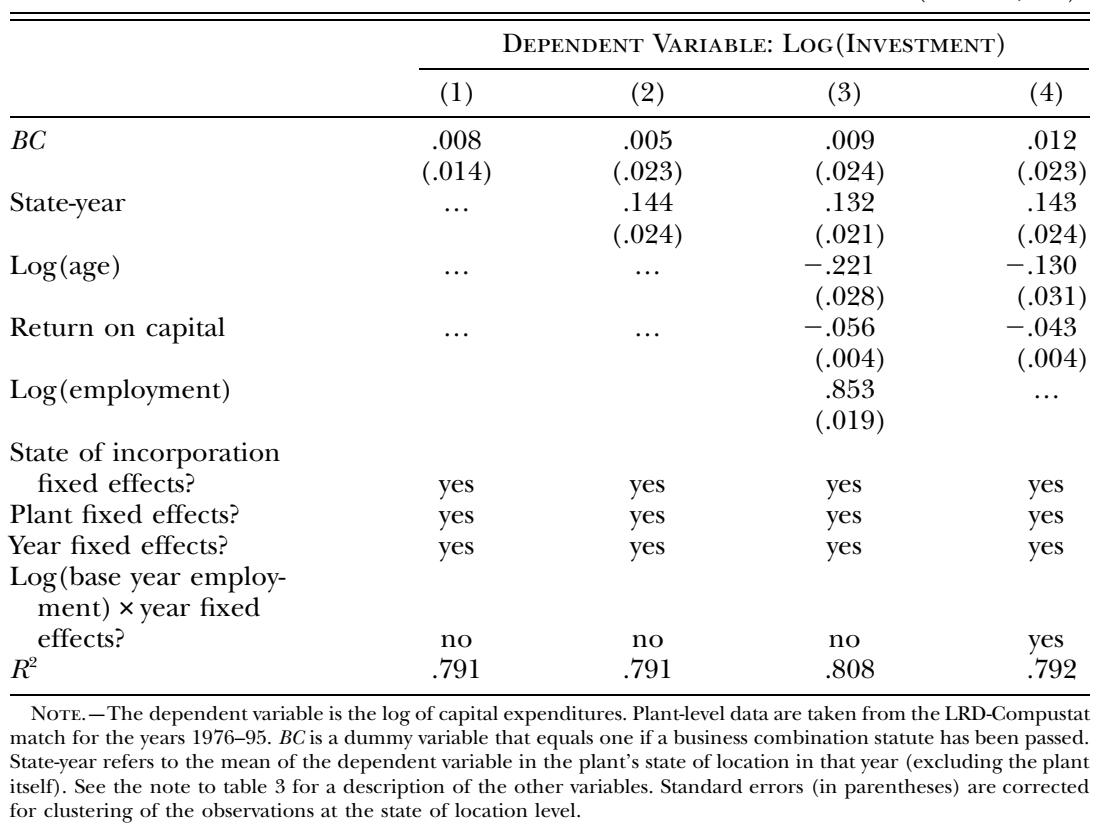

of location-year cell (col. 2) or plant-level characteristics (col. 3) or allow for differential time shocks by plant size (col. 4).

Table 8 confirms that there is no clear impact of the reduction in takeover threat on firm size. In order to look at company size as the dependent variable, we collapse our plant-level database into companyyear cells. We propose four different measures of company size: logarithm of the number of plants (col. 1), logarithm of capital stock (col. 2), logarithm of employment (col. 3), and logarithm of total value of shipment (col. 4). All regressions include firm fixed effects and year fixed effects. For neither of these size measures do we find a significant effect of the business combination legislation. Of course, one could argue that the protected firms are expanding their nonmanufacturing segments, which we cannot measure in the LRD. In regressions not reported here, we have investigated this possibility using Compustat. We found no evidence of a significant change in total (manufacturing and nonmanufacturing) assets among the protected firms.

The combined findings of tables 5, 6, 7, and 8 appear to contradict the predictions of an empire-building model. If managers were interested in building empires, one might have expected them to increase the number of new plants they acquire or build as the laws come into effect. Instead, the birth of new plants is smaller among firms that are 
TABLE 8

Effects of Business Combination Laws on Firm Size $(N=20,468)$

\begin{tabular}{lcccc}
\hline \hline & \multicolumn{4}{c}{ DePendent Variable } \\
\cline { 2 - 5 } & $\begin{array}{c}\text { Log(Number } \\
\text { of Plants) } \\
\end{array}$ & $\begin{array}{c}\text { Log(Capital } \\
\text { Stock) } \\
(1)\end{array}$ & $\begin{array}{c}\log (\text { Employment) } \\
\text { (2) }\end{array}$ & $\begin{array}{c}\log (\text { Output) } \\
(4)\end{array}$ \\
\hline$B C$ & -.007 & .022 & -.008 & -.011 \\
Firm fixed effects? & $(.016)$ & $(.023)$ & $(.019)$ & $(.020)$ \\
Year fixed effects? & yes & yes & yes & yes \\
$R^{2}$ & yes & yes & yes & yes \\
\hline
\end{tabular}

Note.-Firm-level data are taken from the LRD-Compustat match for the years 1976-95. BC is a dummy variable that equals one if a business combination statute has been passed. State-year refers to the mean of the dependent variable in the plant's state of location in that vear (excluding the plant itself). See the note to table 3 for a description of the other variables. Standard errors (in parentheses) are corrected for clustering of the observations at the state of location level.

protected from hostile takeovers. Our findings are in fact much more consistent with a quiet life hypothesis, in which managers are reluctant to undertake cognitively difficult activities. They are less likely to shut down old plants, which may require facing down unions, engaging in layoffs, and dealing with the management in charge of those plants. They are also less likely to open new plants, which may require finding the appropriate projects, adapting to a new industry, and perhaps upsetting the balance of power between managers inside the firm. ${ }^{20}$

A few papers have previously empirically investigated the relevance of the empire-building model. For example, Lewellen, Loderer, and Rosenfeld (1989) focus on acquisition activity and find that bidder announcement returns are most negative when managers have a smaller equity stake in their firm. This study is intriguing because its evidence contrasts with our findings. One possible explanation is that by sampling acquisition episodes, they necessarily oversample managers who are empire builders. Our results, on the other hand, pertain to the average manager. Other papers have investigated empire building for the average firm but rely on much more endogenous or noisier measures of corporate governance (Edwards 1977; Hannan and Mavinga 1980; Aggarwal and Samwick 1999).

\section{Productivity and Profitability}

We now investigate the effect of these laws on overall efficiency. The efficiency effect should summarize the cumulative effect of the changes

${ }^{20}$ Another aspect of the empire-building view that has received attention in the literature is managers' desire to diversify (see, e.g., Morck, Shleifer, and Vishny 1990; Lang and Stulz 1994; Berger and Ofek 1995). We found no evidence in our data set of an increase in diversification following the antitakeover legislation. 
documented above as well as, perhaps, changes on dimensions we have not investigated. If the changes in investment, disinvestment, and worker compensation documented above reflect inefficient behaviors by uncontrolled (or less controlled) managers, one might expect these changes to be accompanied by a reduction in efficiency. In theory, though, a possibly countervailing force would be an increase in firmspecific human capital in the treated plants due to a higher level of stakeholder protection (see Shleifer and Summers 1988; Blair 1995). It is also possible that market forces induce excessive myopia, for example, forcing managers to build and destroy plants just to signal that they are productive (Stein 1988). Given these alternative models, documenting the effect on overall efficiency should both increase our understanding of the laws and help us better interpret the effects documented above.

In order to assess the effects of these laws on efficiency, we use two measures. The first is a measure of total factor productivity (TFP). To measure TFP, we follow Lichtenberg (1992) and estimate the following ordinary least squares regression separately for each three-digit standard industrial classification industry and year:

$$
\begin{aligned}
\log \left(\text { output }_{i}\right)= & \alpha \log \left(\text { wage bill }_{i}\right)+\beta \log \left(\text { capital }_{i}\right) \\
& +\gamma \log \left(\text { material }_{i}\right)+\epsilon_{i},
\end{aligned}
$$

where $i$ indexes plants, output ${ }_{i}$ is the total value of shipments, wage bill $_{i}$ is the total wage bill, capital ${ }_{i}$ is the value of the capital stock, and material ${ }_{i}$ is the cost of material shipments. ${ }^{21}$ Using the residuals from the regressions above, we then compute the percentile (.01 being the first percentile) in which a given plant-year observation falls in the distribution of TFP in that observation's industry and year.

Our second measure of efficiency is simply return on capital. This measure complements the TFP measure in at least two ways. First, it does not suffer from functional form and estimation issues usually associated with computing TFP. Second, return on capital gives us a better approximation of what shareholders eventually receive.

Our findings for TFP and profitability are reported in table 9. Columns 1-5 focus on the TFP measure, and columns $6-10$ focus on the return on capital measure. All regressions include state of incorporation fixed effects, plant fixed effects, and year fixed effects. Note that by the way of constructing the TFP measure, we are implicitly including industry-year fixed effects in columns 1-5.

In our basic specification, we find that the business combination laws lead to a drop of more than one percentile in relative productivity. This

\footnotetext{
${ }^{21}$ The results are qualitatively unchanged if we focus on two-digit instead of three-digit industries. The results are also unaffected if we use production hours instead of total wage bill as a measure of labor input.
} 
TABLE 9

Effects of Business Combination Laws on Productivity and Profitability

\begin{tabular}{|c|c|c|c|c|c|c|c|c|c|c|}
\hline & \multicolumn{10}{|c|}{ DEPENDENT Variable } \\
\hline & \multicolumn{5}{|c|}{ TFP Percentile $(N=190,171)$} & \multicolumn{5}{|c|}{ Return on Capital $(N=191,439)$} \\
\hline & (1) & (2) & (3) & (4) & $(5)$ & (6) & (7) & (8) & (9) & $(10)$ \\
\hline$\overline{B C}$ & $\begin{array}{c}-.013 \\
(.005)\end{array}$ & $\begin{array}{c}-.013 \\
(.005)\end{array}$ & $\begin{array}{c}-.013 \\
(.004)\end{array}$ & $\begin{array}{c}-.011 \\
(.004)\end{array}$ & $\ldots$ & $\begin{aligned}-.008 \\
(.004)\end{aligned}$ & $\begin{aligned}-.008 \\
(.004)\end{aligned}$ & $\begin{array}{r}-.007 \\
(.004)\end{array}$ & $\begin{array}{c}-.002 \\
(.004)\end{array}$ & $\ldots$ \\
\hline State-year & $\ldots$ & $\begin{array}{l}.115 \\
(.061)\end{array}$ & $\begin{array}{l}.112 \\
(.059)\end{array}$ & $\begin{array}{l}.118 \\
(.059)\end{array}$ & $\begin{array}{l}.116 \\
(.061)\end{array}$ & $\ldots$ & $\begin{array}{l}.150 \\
(.067)\end{array}$ & $\begin{array}{l}.131 \\
(.063)\end{array}$ & $\begin{array}{l}.137 \\
(.063)\end{array}$ & $\begin{array}{l}.149 \\
(.066)\end{array}$ \\
\hline $\log ($ age $)$ & $\ldots$ & $\ldots$ & $\begin{array}{l}.022 \\
(.005)\end{array}$ & $\begin{array}{l}.019 \\
(.005)\end{array}$ & $\ldots$ & $\ldots$ & $\ldots$ & $\begin{array}{l}.014 \\
(.005)\end{array}$ & $\begin{array}{c}-.000 \\
(.006)\end{array}$ & $\ldots$ \\
\hline Log (employment) & $\ldots$ & $\ldots$ & $\begin{array}{l}.021 \\
(.004)\end{array}$ & $\ldots$ & $\ldots$ & $\ldots$ & $\ldots$ & $\begin{array}{l}.065 \\
(.004)\end{array}$ & $\ldots$ & $\ldots$ \\
\hline Before $^{-1}$ & $\ldots$ & $\ldots$ & $\ldots$ & $\ldots$ & $\begin{array}{r}-.003 \\
(.003)\end{array}$ & $\ldots$ & $\ldots$ & $\ldots$ & $\ldots$ & $\begin{array}{r}-.003 \\
(.003)\end{array}$ \\
\hline Before $^{0}$ & $\ldots$ & $\ldots$ & $\ldots$ & $\ldots$ & $\begin{array}{r}-.006 \\
(.004)\end{array}$ & $\ldots$ & $\ldots$ & $\ldots$ & $\ldots$ & $\begin{array}{r}-.004 \\
(.004)\end{array}$ \\
\hline After $^{1}$ & $\ldots$ & $\ldots$ & $\ldots$ & $\ldots$ & $\begin{array}{c}-.018 \\
(.005)\end{array}$ & $\ldots$ & $\ldots$ & $\ldots$ & $\ldots$ & $\begin{array}{r}-.011 \\
(.005)\end{array}$ \\
\hline After $^{2+}$ & $\ldots$ & $\ldots$ & $\ldots$ & $\ldots$ & $\begin{array}{c}-.022 \\
(.007)\end{array}$ & $\ldots$ & $\ldots$ & $\ldots$ & $\ldots$ & $\begin{array}{c}-.014 \\
(.007)\end{array}$ \\
\hline $\begin{array}{l}\log (\text { base year employment }) \times \text { year fixed } \\
\text { effects? }\end{array}$ & no & $\mathrm{n}$ & $\mathrm{n}$ & ye & $\mathrm{n}$ & no & no & no & yes & no \\
\hline State of incorporation fixed effects? & yes & yes & yes & yes & yes & yes & yes & yes & yes & yes \\
\hline Plant fixed effects? & yes & yes & yes & yes & yes & yes & yes & yes & yes & yes \\
\hline Year fixed effects? & yes & yes & yes & yes & yes & yes & yes & yes & yes & yes \\
\hline$R^{2}$ & .552 & .552 & .553 & .553 & .552 & .666 & .666 & .671 & .670 & .666 \\
\hline
\end{tabular}

NoTE.-Plant-level data are taken from the LRD-Compustat match for the years 1976-95. $B C$ is a dummy variable that equals one if a business combination statute has been passed. State-year refers to the mean of the dependent variable in the plant's state of location in that year (excluding the plant itself). See the note to table 3 for cols. $6-10$, state-year refers to the mean of the return on capital in the plant's state of location in that vear (excluding the plant itself). Standard errors (in parentheses) are corrected for clustering of the observations at the state of location level. 
finding is unaffected when we further control for mean TFP percentile (col. 2) in the state of location-year cell. Also, this finding is robust to further controlling for age of plant and plant-level employment (col. 3 ). In column 4, we allow for differential time shocks by plant size. The TFP finding is again unchanged.

These results appear inconsistent with the idea that the increased protection of workers led them to increase their firm-specific or plantspecific investment. One could still argue that we are capturing only a transitional drop in productivity as new human capital investments are being undertaken, which may have a temporary disruptive impact on productivity. We address this issue in column 5, where we study the dynamic effects of the business combination laws on TFP. It appears that the drop in productivity is not concentrated in the years just after the adoption of the antitakeover legislation. In fact, the decline in productivity is strongest two years or more after the legislative changes. We therefore find no evidence of positive effects of stakeholder protection in our data. Transferring rents to workers does not generate a rise in efficiency. Note also from column 5 that there is no evidence that the observed decline in TFP preceded the legislative changes, which again is consistent with a causal interpretation of the finding.

Qualitatively similar results hold in columns 6-10, where we focus on return on capital as the dependent variable. The introduction of the antitakeover legislation leads to about an 0.8 percent drop in return on capital in the affected plants. One exception is column 9, where we see that the estimated coefficient on $B C$ appears sensitive to the inclusion of differential time shocks by plant size.

\section{Robustness Checks}

Table 10 investigates the robustness of our results to alternative sample choices. Each coefficient in this table corresponds to a separate regression. Reported is the estimated coefficient on the $B C$ dummy in the basic specification for a set of dependent variables.

First, the bulk of firms (45 percent) are located in one state: Delaware. How much are our results driven by this one law? In column 1, we limit the sample to the set of firms that are not incorporated in Delaware. As we can see, our findings are statistically robust to this drastic reduction in sample size. Moreover, the sizes of the estimated effects are very similar to those obtained in the full sample. This is interesting because it contrasts with the argument made by some commentators that the Delaware law was relatively less stringent. For example, the Delaware law requires a three- rather than a five-year freeze-out period. Our results suggest that perhaps these differences did not translate in the de facto stringency of the law. An alternative interpretation could be that Del- 
TABLE 10

Effects of Business Combination Laws: Robustness to Sample Choices

\begin{tabular}{lccc}
\hline \hline & \multicolumn{3}{c}{ SAMPLE } \\
\cline { 2 - 4 } Den-Delaware & Treated States & Year $\geq 1987$ \\
\hline Log(blue-collar wage) & $(1)$ & $(2)$ & .007 \\
& .010 & .006 & $(.003)$ \\
Death dummy & $.006)$ & $-.005)$ & $(.017$ \\
Birth dummy & -.025 & $(.003)$ & -.014 \\
& $(.005)$ & -.025 & $(.004)$ \\
TFP percentile & -.014 & $(.005)$ & -.013 \\
& $(.004)$ & -.008 & $(.005)$ \\
\hline
\end{tabular}

Note.-Firm-level data are taken from the LRD-Compustat match for the years 1976-95. Each cell in the table corresponds to a different regression. The reported number is the estimated coefficient on $B C$, a dummy variable that equals one if a business combination statute has been passed. Included in the $\log$ (blue-collar wage) and TFP percentile regressions are plant fixed effects, year fixed effects, and the mean of the respective dependent variable in the plant's state of location in that year (excluding the plant itself). Included in the death dummy and birth dummy regressions can (exclute of location in that year (excluding the plant itself). Non-Delaware limits the sample to the set of firms that are no incorporated in Delaware. Treated states limits the sample to the set of firms incorporated in a passing state, i.e., a state that passes antitakeover legislation at some point in the sample period. Year $\geq 1987$ limits the sample to the $1987-95$ period. Standard errors (in parentheses) are corrected for clustering of the observations at the state of location level.

aware firms are, on average, bigger. If bigger firms were more affected by the takeover statutes, then even a weaker Delaware law could have as big of an overall effect simply because the firms it covers were more sensitive to the new statutes.

A second concern is whether nonpassing states form a good control for passing states. For example, as we saw in table 2, plants in nonpassing states are smaller, on average, than plants in passing states. The staggering of the passage of the laws allows us to reestimate all our results using only passing states. This is the exercise we perform in column 2. All the results carry through in this alternative sample except for the wage effect, which stays positive but becomes statistically insignificant.

A third concern is that our data construction leads us to sample only firms that exist in $1987 .{ }^{22}$ Yet in our regressions we use data prior to 1987. This raises questions of whether our regressions might suffer from sample selection. By conditioning on firms that exist in 1987, we are surely selecting firms with different trends in the pre- 1987 period. While it is not clear how this would correlate with the antitakeover legislation, it might still be a source of concern. In column 3, we therefore reestimate all our regressions for only the 1987-95 subperiod. One must still be careful in interpreting our results since our data contain no firm births after 1987. But this is not a source of bias, merely an interpretation issue. It means that our results are the effect of takeover laws on firms

\footnotetext{
${ }^{22}$ Recall, however, that we record all plant births and deaths for the firms in our sample throughout the sample period.
} 
that were in existence in 1987. Once again, we see that the results are unaffected in this alternative sample.

For space reasons, we shall summarize without directly reporting other robustness tests we performed. First, we reestimated all the basic models allowing for differential time trends between the passing and the nonpassing states; the results were unaffected except for the blue-collar wage effect, which became only marginally significant at conventional levels. Second, we reestimated all the regressions allowing for differential time shocks by two-digit industry; the results were unaffected. Third, we replicated all of the analysis for larger plants only, which are sampled with probability one in each year; the results were unaffected. Fourth, we replaced $y_{t t(-i)}$ with a full set of region of location dummies (regions are the 10 census regions) interacted with year dummies; the results were unchanged. Finally, we also allowed for differential time shocks by firm base year size; again, the results were unaffected.

\section{Conclusion and Extensions}

The results of this paper suggest that reductions in corporate governance have real effects on firm behavior. We found that antitakeover laws generated rises in blue-collar workers' wages and even larger rises in white-collar workers' wages. This suggests that managers prefer to pay workers (especially white-collar ones) higher wages, which is consistent with stakeholder theories of the firm. However, we found that these higher wages did not, on net, translate into greater operating efficiency, suggesting that stakeholder protection did not "pay for itself." We also found evidence of a decline in the level of both plant creation and destruction, with little effect on overall firm size. The fall, rather than rise, in plant creation suggests an important fact about managerial preferences. The average manager might be better characterized by what we term "quiet life" models than by empire-building models. The average manager in our sample does not appear to try to increase firm size. Instead, he seems to avoid creating new plants as much as he avoids destroying old ones.

Antitakeover legislation could be used in the future to address other questions about corporate governance. First, one could learn about the interactions between different governance mechanisms. Do firms in more or less competitive industries respond differently to these laws? What about firms with a large shareholder or fewer insiders on the board? One could also expand this line of reasoning beyond governance mechanisms and look at the effect of internal power structures. For example, does the presence of unions increase the amount transferred to workers? Second, one could learn about the dynamics of corporate governance. Does the number of large shareholders rise to partially 
compensate for the reduction in threats of hostile takeover? Alternatively, does the reduction in threats of hostile takeover give management room to get even more entrenched, say by placing more insiders on the board?

\section{References}

Aggarwal, Rajesh, and Samwick, Andrew. "Empire Builders and Shirkers: Investment, Firm Performance, and Managerial Incentives." Manuscript. Hanover, N.H.: Dartmouth Coll., 1999.

Baumol, William J. Business Behavior, Value and Growth. New York: Macmillan, 1959.

Berger, Philip G., and Ofek, Eli. "Diversification's Effect on Firm Value.” J. Financial Econ. 37 (January 1995): 39-65.

Bertrand, Marianne; Duflo, Esther; and Mullainathan, Sendhil. "How Much Should We Trust Differences-in-Differences Estimates?" Working Paper no. 8841. Cambridge, Mass.: NBER, March 2002.

Bertrand, Marianne, and Mullainathan, Sendhil. "Corporate Governance and Executive Pay: Evidence from Takeover Legislation.” Manuscript. Princeton, N.J.: Princeton Univ., 1999. (a)

. "Is There Discretion in Wage Setting? A Test Using Takeover Legislation." Rand J. Econ. 30 (Autumn 1999): 535-54. (b)

Blair, Margaret M. Ownership and Control: Rethinking Corporate Governance for the Twenty-first Century. Washington: Brookings Inst., 1995.

Block, Dennis; Barton, Nancy; and Roth, Andrea. "State Takeover Statutes: The 'Second Generation."' Securities Regulation Law J. 13 (Winter 1986): 332-55.

Bradley, Michael. "Interfirm Tender Offers and the Market for Corporate Control." J. Bus. 53 (October 1980): 345-76.

Bradley, Michael; Desai, Anand; and Kim, E. Han. "The Rationale behind Interfirm Tender Offers: Information or Synergy?” J. Financial Econ. 11 (April 1983): 183-206.

Brown, Charles C., and Medoff, James L. "The Impact of Firm Acquisitions on Labor." In Corporate Takeovers: Causes and Consequences, edited by Alan J. Auerbach. Chicago: Univ. Chicago Press (for NBER), 1988.

Comment, Robert, and Schwert, G. William. "Poison or Placebo? Evidence on the Deterrence and Wealth Effects of Modern Antitakeover Measures." J. Financial Econ. 39 (September 1995): 3-43.

Davis, Steven J.; Haltiwanger, John C.; and Shuh, Scott. Job Creation and Destruction. Cambridge, Mass.: MIT Press, 1996.

DeAngelo, Harry, and Rice, Edward M. "Antitakeover Charter Amendments and Stockholder Wealth.” J. Financial Econ. 11 (April 1983): 329-59.

Dodd, Peter. "Merger Proposals, Management Discretion and Stockholder Wealth." J. Financial Econ. 8 (June 1980): 105-37.

Easterbrook, Frank H., and Fischel, Daniel R. The Economic Structure of Corporate Law. Cambridge, Mass.: Harvard Univ. Press, 1991.

Edwards, Franklin R. "Managerial Objectives in Regulated Industries: ExpensePreference Behavior in Banking." J.P.E. 85 (February 1977): 147-62.

Garvey, Gerald T., and Hanka, Gordon. "Capital Structure and Corporate Control: The Effect of Antitakeover Statutes on Firm Leverage.” J. Finance 54 (April 1999): 519-46. 
Grinblatt, Mark, and Titman, Sheridan. Financial Markets and Corporate Strategy. Boston: Irwin/McGraw-Hill, 1998.

Hackl, Jo Watson, and Testani, Rosa Anna. "Second Generation State Takeover Statutes and Shareholder Wealth: An Empirical Study." Yale Law J. 97 (May 1988): 1193-1231.

Hannan, Timothy H., and Mavinga, Ferdinand. "Expense Preference and Managerial Control: The Case of the Banking Firm." Bell J. Econ. 11 (Autumn 1980): 671-82.

Hicks, John R. "Annual Survey of Economic Theory: The Theory of Monopoly." Econometrica 3 (January 1935): 1-20.

Jarrell, Gregg A., and Poulsen, Annette B. "Shark Repellents and Stock Prices: The Effects of Antitakeover Amendments since 1980." J. Financial Econ. 19 (September 1987): 127-68.

Kaplan, Steven. "The Effects of Management Buyouts on Operating Performance and Value." J. Financial Econ. 24 (October 1989): 217-54.

Karpoff, Jonathan M., and Malatesta, Paul H. "The Wealth Effects of SecondGeneration State Takeover Legislation.” J. FinancialEcon. 25 (December 1989): 291-322.

Lang, Larry H. P., and Stulz, Rene M. “Tobin's $q$, Corporate Diversification, and Firm Performance.” J.P.E. 102 (December 1994): 1248-80.

Lewellen, Wilbur; Loderer, Claudio; and Rosenfeld, Ahron. "Mergers, Executive Risk Reduction, and Stockholder Wealth." J. Financial and Quantitative Analysis 24 (December 1989): 459-72.

Lichtenberg, Frank R. Corporate Takeovers and Productivity. Cambridge, Mass.: MIT Press, 1992.

Lichtenberg, Frank R., and Siegel, Donald. "The Effects of Leveraged Buyouts on Productivity and Related Aspects of Firm Behavior." J. Financial Econ. 27 (September 1990): 165-94.

Margotta, Donald G.; McWilliams, Thomas P.; and McWilliams, Victoria B. "An Analysis of the Stock Prices Effect of the 1986 Ohio Takeover Legislation." J. Law, Econ., and Organization 6 (Spring 1990): 235-51.

Marris, Robin L. The Economic Theory of Managerial Capitalism. London: Macmillan, 1964.

Matheson, John H., and Olson, Brent A. "Shareholder Rights and Legislative Wrongs: Toward Balanced Takeover Legislation.” George Washington Law Rev. 59 (August 1991): 1425-1569.

Morck, Randall; Shleifer, Andrei; and Vishny, Robert W. "Do Managerial Objectives Drive Bad Acquisitions?" J. Finance 45 (March 1990): 31-48.

Ofek, Eli, and Yermack, David. "Taking Stock: Equity-Based Compensation and the Evolution of Managerial Ownership." J. Finance 55 (June 2000): 1367-84.

Pound, John. "The Effects of Antitakeover Amendments on Takeover Activity: Some Direct Evidence." J. Law and Econ. 30 (October 1987): 353-67.

Romano, Roberta. "The Political Economy of Takeover Statutes." Virginia Law Rev. 73 (February 1987): 111-99.

- "Competition for Corporate Charters and the Lesson of Takeover Statutes." Fordham Law Rev. 61 (March 1993): 843-64.

Rosett, Joshua G. "Do Union Wealth Concessions Explain Takeover Premiums? The Evidence on Contract Wages." J. Financial Econ. 27 (September 1990): 263-82.

Schumann, Laurence. "State Regulation of Takeovers and Shareholder Wealth: The Case of New York's 1985 Takeover Statutes.” Rand J. Econ. 19 (Winter 1988): 557-67. 
Shleifer, Andrei, and Summers, Lawrence H. "Breach of Trust in Hostile Takeovers." In Corporate Takeovers: Causes and Consequences, edited by Alan J. Auerbach. Chicago: Univ. Chicago Press (for NBER), 1988.

Shleifer, Andrei, and Vishny, Robert W. "A Survey of Corporate Governance." J. Finance 52 (June 1997): 737-83.

Sroufe, Evelyn, and Gelband, Catherine. "Business Combination Statutes: A 'Meaningful' Opportunity for Success?” Bus. Lawyer 45 (May 1990): 891-921.

Stein, Jeremy C. "Takeover Threats and Managerial Myopia." J.P.E. 96 (February 1988): 61-80.

Szewczyk, Samuel H., and Tsetsekos, George P. "State Intervention in the Market for Corporate Control: The Case of Pennsylvania Senate Bill 1310." J. Financial Econ. 31 (February 1992): 3-23.

Williamson, Oliver E. The Economics of Discretionary Behavior: Managerial Objectives in a Theory of the Firm. Englewood Cliffs, N.J.: Prentice-Hall, 1964. 